\title{
Universiteit
}

Leiden

The Netherlands

\section{Metal requirements of low-carbon power generation}

Kleijn, R.; Voet, E. van der; Kramer, G.J.; Oers, L. van; Giesen, C.C. van der

\section{Citation}

Kleijn, R., Voet, E. van der, Kramer, G. J., Oers, L. van, \& Giesen, C. C. van der. (2011). Metal requirements of low-carbon power generation. Energy, 36(9), 5640-5648. doi:10.1016/j.energy.2011.07.003

Version: $\quad$ Publisher's Version

License: $\quad$ Licensed under Article 25fa Copyright Act/Law (Amendment Taverne)

Downloaded from: https://hdl.handle.net/1887/3193898

Note: To cite this publication please use the final published version (if applicable). 


\title{
Metal requirements of low-carbon power generation
}

\author{
René Kleijn $^{\mathrm{a}, *}$, Ester van der Voet ${ }^{\mathrm{a}}$, Gert Jan Kramer $^{\mathrm{a}, \mathrm{b}}$, Lauran van Oers ${ }^{\mathrm{a}}$, Coen van der Giesen ${ }^{\mathrm{a}}$ \\ a Institute of Environmental Sciences (CML), Leiden University, P.O. Box 9518, 2333 CC Leiden, The Netherlands \\ ${ }^{\mathrm{b}}$ Shell Global Solutions International BV, PO Box 3800, 1030 BN Amsterdam, The Netherlands
}

\section{A R T I C L E I N F O}

\section{Article history:}

Received 4 February 2011

Received in revised form

1 July 2011

Accepted 3 July 2011

Available online 6 August 2011

\section{Keywords:}

Material requirements

Electricity

Metals

LCA

\begin{abstract}
A B S T R A C T
Today, almost $70 \%$ of the electricity is produced from fossil fuels and power generation accounts for over $40 \%$ of global $\mathrm{CO}_{2}$ emissions. If the targets to reduce climate change are to be met, substantial reductions in emissions are necessary. Compared to other sectors emission reductions in the power sector are relatively easy to achieve because it consists mainly of point-sources. Carbon Capture and Storage (CCS) and the use of low-carbon alternative energy sources are the two categories of options to reduce $\mathrm{CO}_{2}$ emissions. However, for both options additional infrastructure and equipment is needed. This article compares $\mathrm{CO}_{2}$ emissions and metal requirements of different low-carbon power generation technologies on the basis of Life Cycle Assessment. We analyze the most critical output $\left(\mathrm{CO}_{2}\right)$ and the most critical input (metals) in the same methodological framework. $\mathrm{CO}_{2}$ emissions and metal requirements are compared with annual global emissions and annual production for different metals. It was found that all technologies are very effective in reducing $\mathrm{CO}_{2}$ emissions. However, CCS and especially non-fossil technologies are substantially more metal intensive than existing power generation. A transition to a low-carbon based power generation would require a substantial upscaling of current mining of several metals.
\end{abstract}

(c) 2011 Elsevier Ltd. All rights reserved.

\section{Introduction}

The demand for electricity has been rising steadily ever since its introduction in the late 19th century [1]. Since 1980 the average annual growth in demand has been over $3 \%$ and this growth is projected to continue in the future [2]. The expected introduction of new technologies such as electric vehicles and heat pumps may even accelerate this demand growth in the future. In 2007 the installed capacity for power generation was over $4000 \mathrm{GW}$ and the world electricity production in that year was almost $20,000 \mathrm{TWh}$ [2]. Almost 70\% of this electricity is produced from fossil fuels [3] mainly coal (41\%) and natural gas (21\%). Power generation accounts for over $40 \%$ of global $\mathrm{CO}_{2}$ emissions with an annual emission of $29 \mathrm{Gt}$ in 2007 [4]. Hence, power generation is one of the major contributors to climate change.

If the targets to reduce climate change are to be met, the share of electricity in the energy sector should increase while the emissions from this sector should be substantially reduced. According to the

\footnotetext{
* Corresponding author. Tel.: +31 71 5271498; fax: +31 715277434.

E-mail addresses: kleijn@cml.leidenuniv.nl (R. Kleijn), voet@cml.leidenuniv.nl (E. van der Voet), kramer@cml.leidenuniv.nl, gertjan.kramer@shell.com (G. J. Kramer), oers@cml.leidenuniv.nl (L. van Oers), coenvandergiesen@hotmail.com (C. van der Giesen).
}

IPCC, emissions need to be reduced by $50-85 \%$ below 2000 levels by 2050 , in order to stabilize atmospheric $\mathrm{CO}_{2}$ concentrations at 450-490 ppm [5]. This is estimated to correspond with a temperature increase of $2-2.4{ }^{\circ} \mathrm{C}$. More than half of this decrease can be achieved by efficiency improvements, the remainder would have to come from Carbon Capture and Storage (CCS) and non-fossil alternatives [2].

\subsection{Material requirements of power generation}

In this paper we explore how and to what extent material requirements may constrain the scale up of low-carbon power generation technologies. In an earlier study we found that for some specific technologies the use of minor metals may prevent them from growing to a significant global scale [6]. The requirements of minor metals will not be discussed here. Next to these minor metals it is also clear that in general the material intensity of new energy technologies is higher than for existing technologies. For CCS this is a logical consequence of the additional infrastructure that is needed for the capture, transport and storage of $\mathrm{CO}_{2}$ in combination with the loss of efficiency in power plants. For non-fossil technologies this is related to the relatively high material intensity that is needed for harvesting energy from diffuse sources, such as wind and sunlight. 
Table 1

Electricity mix in different cases based on the 2007 global power generation of 19855 TWh [3].

\begin{tabular}{|c|c|c|c|c|c|c|c|c|}
\hline & \multicolumn{2}{|c|}{ Current mix } & \multicolumn{2}{|l|}{ CCS } & \multicolumn{2}{|c|}{ Low-carbon } & \multicolumn{2}{|c|}{ IEA BLUE Map } \\
\hline & $\%$ & TWh & $\%$ & TWh & $\%$ & TWh & $\%$ & TWh \\
\hline Coal & $41.4 \%$ & 8220 & & & & & $0 \%$ & \\
\hline Coal + CCS & & & $41.8 \%$ & 8302 & & & $14 \%$ & 2694 \\
\hline Natural gas & $20.8 \%$ & 4130 & & & & & $4 \%$ & 863 \\
\hline Natural gas + CCS & & & $21.0 \%$ & 4171 & & & $14 \%$ & 2689 \\
\hline Oil & $5.6 \%$ & 1112 & & & & & $0 \%$ & 66 \\
\hline $\mathrm{Oil}+\mathrm{CCS}$ & & & $5.7 \%$ & 1123 & & & $0 \%$ & 0 \\
\hline Nuclear & $13.7 \%$ & 2720 & $13.8 \%$ & 2747 & $20 \%$ & 3971 & $24 \%$ & 4856 \\
\hline Hydro & $15.6 \%$ & 3097 & $15.8 \%$ & 3128 & $10 \%$ & 1986 & $13 \%$ & 2591 \\
\hline Biomass rape seed oil & & & & & $15 \%$ & 2978 & $3 \%$ & 604 \\
\hline Biomass waste wood chips in $\mathrm{CHP}$ & $0.96 \%$ & 191 & $0.97 \%$ & 193 & $15 \%$ & 2978 & $3 \%$ & 604 \\
\hline Wind & $0.87 \%$ & 173 & $0.88 \%$ & 174 & $20 \%$ & 3971 & $13 \%$ & 2549 \\
\hline PV solar & $0.02 \%$ & 4 & $0.02 \%$ & 4 & $20 \%$ & 3971 & $12 \%$ & 2342 \\
\hline Others & $1.1 \%$ & 218 & & & & & & \\
\hline Total & $100 \%$ & 19865 & $100 \%$ & 19843 & $100 \%$ & 19855 & $100 \%$ & 19855 \\
\hline
\end{tabular}

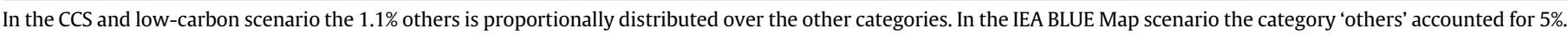
This $5 \%$ was also proportionally distributed over the other categories.

\subsection{Goal of the study}

In this article we will present an analysis of the effectiveness of $\mathrm{CO}_{2}$ emission reduction and the requirements of selected metals in low-carbon electricity technologies: iron, aluminum, nickel, copper, zinc, tin, molybdenum, silver and uranium. These metals are chosen as a mix of major metals that are important for the general infrastructure: iron, aluminum, copper and zinc; metals that are important for special alloys: nickel, tin and molybdenum; and metals that are important for specific technologies: silver and uranium.

The main research questions addressed here are:

1. to what extent can CCS and current non-fossil technologies contribute to $\mathrm{CO}_{2}$ emission reduction targets of $50-85 \%$ ?

2. what are the metal requirements of these CCS and non-fossil technologies?

3. how does this metal demand compare to current mine production?

We will start by comparing $\mathrm{CO}_{2}$ emissions and metal requirements of different electricity producing technologies on a life cycle basis. After that $\mathrm{CO}_{2}$ emissions and metal requirements of four cases will be compared:

a the current electricity mix [3]

- the current electricity mix but with the assumption that all fossil fuel based electricity would be fitted with CCS

- an electricity mix consisting of only existing non-fossil technologies

- the 2050 electricity mix as described in the IEA Blue Map Scenario [7].

The emissions and metal requirements are then compared with annual global $\mathrm{CO}_{2}$ emissions and annual mine production for different metals. Possible bottlenecks are identified and possible solutions are discussed.

\subsection{Other constraints for low-carbon power generation}

Material availability is only one of several factors that might constrain the scale up of the low-carbon electricity technologies. Although these are not the subject of this paper, the most important constraints are briefly discussed in this section: economic constraints, constraints of industrial capacity and spatial and infrastructure planning.

Under the existing economic regime, low-carbon electricity technologies are often more expensive than the dominant fossil fuel based technologies. Only large scale hydropower, nuclear power and wind turbines can compete with fossil fuel based electricity under specific circumstances, while the production price

Table 2

Description of power generation pathways, basic data from Ecoinvent 2.0.

\begin{tabular}{|c|c|c|}
\hline Abbreviation & Description & Additional data \\
\hline \multicolumn{3}{|l|}{ Current mix electricity } \\
\hline Coal & $\begin{array}{l}\text { Production of electricity via } \\
\text { burning of coal UCTE (European } \\
\text { weighted average) }\end{array}$ & - \\
\hline Natural gas & $\begin{array}{l}\text { Production of electricity via } \\
\text { burning of natural gas UCTE } \\
\text { (European weighted average) }\end{array}$ & - \\
\hline Oil & $\begin{array}{l}\text { Production of electricity via } \\
\text { burning of crude oil UCTE } \\
\text { (European weighted average) }\end{array}$ & - \\
\hline Nuclear & $\begin{array}{l}\text { Production of electricity in } \\
\text { nuclear power plant UCTE } \\
\text { (European weighted average) }\end{array}$ & - \\
\hline Wind & $\begin{array}{l}\text { Production of electricty with } \\
2 \text { MW offshore wind } \\
\text { turbine OCE }\end{array}$ & - \\
\hline Solar & $\begin{array}{l}\text { Production of electricity with } \\
3 \mathrm{kWp} \text { flat roof PV installations } \\
\text { based on mc-Si }\end{array}$ & - \\
\hline Biomass & $\begin{array}{l}\text { Rape seed oil in oil fired } \\
\text { power plant }\end{array}$ & $\begin{array}{l}\text { A combination of } \\
\text { two ecoinvent } \\
\text { processes: rape } \\
\text { seed oil } \\
\text { production and an } \\
\text { oil fired power } \\
\text { plant }\end{array}$ \\
\hline Biomass & CHP waste wood chips & - \\
\hline $\begin{array}{l}\text { Hydro } \\
\text { Electricity with CCS }\end{array}$ & Alpine region hydropower & - \\
\hline Coal + CCS & $\begin{array}{l}\text { As coal but with Carbon } \\
\text { Capture and Storage (CCS) }\end{array}$ & CCS [24] \\
\hline Natural Gas + CCS & $\begin{array}{l}\text { As gas but with Carbon } \\
\text { Capture and Storage (CCS) }\end{array}$ & CCS [24] \\
\hline Oil + CCS & $\begin{array}{l}\text { As coal but with Carbon } \\
\text { Capture and Storage (CCS) }\end{array}$ & CCS [24] \\
\hline Biomass + CCS & $\begin{array}{l}\text { As biomass but with } \\
\text { Carbon Capture and } \\
\text { Storage as in } \\
\text { natural gas CCS }\end{array}$ & CCS [24] \\
\hline
\end{tabular}


Table 3

Basic data natural gas and coal power plants with CCS (based on [24]).

\begin{tabular}{|c|c|c|c|}
\hline & Natural gas & Coal & Source \\
\hline \multicolumn{4}{|l|}{ Power plant } \\
\hline Type & Combined Cycle & Pulverized coal & [39] \\
\hline Size & $400 \mathrm{MWe}$ & $400 \mathrm{MWe}$ & [39] \\
\hline Efficiency & $57.7 \%$ & $35.9 \%$ & [39] \\
\hline Lifetime & $180,000 \mathrm{~h}$ & $150,000 \mathrm{~h}$ & [39] \\
\hline Operation & 8000 h/a & 8000 h/a & [39] \\
\hline $\mathrm{CO}_{2}$ emission & $\begin{array}{l}350 \mathrm{~g} / \mathrm{kWh} \\
\text { (plant only) }\end{array}$ & $\begin{array}{l}930 \mathrm{~g} / \mathrm{kWh} \\
\text { (plant only) }\end{array}$ & [39] \\
\hline $\mathrm{CO}_{2}$ concentration flue gas & $3.9 \mathrm{~mol} \%$ & $12.8 \mathrm{~mol} \%$ & {$[40,41]$} \\
\hline Steel in construction & 10,600 ton & 35,000 ton & [39] \\
\hline $\begin{array}{l}\text { Efficiency loss due } \\
\text { to capture } \\
\text { and compression }\end{array}$ & $25 \%$ & $15 \%$ & {$[42,43$} \\
\hline \multicolumn{4}{|l|}{ Capture installation } \\
\hline Type & Post combustion & Post combustion & \\
\hline Solvent & $35 \%$ MEA & $35 \% \mathrm{MEA}$ & {$[41]$} \\
\hline Capture efficiency & $90 \%$ & $90 \%$ & [41] \\
\hline Carbon steel & 3700 ton & 5560 ton & {$[24]$} \\
\hline Stainless steel & 950 ton & 1470 ton & {$[24]$} \\
\hline Life time & 30 year & 30 year & {$[24]$} \\
\hline \multicolumn{4}{|l|}{ Compression } \\
\hline Pressure at injection point & 100 bar & 100 bar & {$[24]$} \\
\hline Pressure after compression & 140 bar & 140 bar & {$[24]$} \\
\hline $\begin{array}{l}\text { Weight compressor } \\
\text { and pump }\end{array}$ & 210 ton & 550 ton & [24] \\
\hline Electricity needs & $86.5 \mathrm{kWh} /$ ton $\mathrm{CO}_{2}$ & $86.5 \mathrm{kWh} /$ ton $\mathrm{CO}_{2}$ & {$[24]$} \\
\hline Life time & 15 years & 15 years & [24] \\
\hline \multicolumn{4}{|l|}{ Pipeline } \\
\hline Length & $200 \mathrm{~km}$ & $200 \mathrm{~km}$ & {$[24]$} \\
\hline Size & NPS 10 & NPS 16 & [24] \\
\hline Wall thickness & $6.4 \mathrm{~mm}$ & $8.9 \mathrm{~mm}$ & [24] \\
\hline Weight & $42 \mathrm{~kg} / \mathrm{m}$ & $93 \mathrm{~kg} / \mathrm{m}$ & {$[24]$} \\
\hline Total weight & 8400 ton & 18,600 ton & {$[24]$} \\
\hline \multicolumn{4}{|l|}{ Injection } \\
\hline Depth of well & $1000 \mathrm{~m}$ & $1000 \mathrm{~m}$ & {$[24]$} \\
\hline Number of wells & 1 & 2.7 & {$[24]$} \\
\hline Stainless steel & 210 & 570 & {$[24]$} \\
\hline
\end{tabular}

solar electricity is much higher per kWh produced [8,9]. Furthermore, massive investments are needed for additional infrastructure, either in power transmission for non-fossil energy sources or in $\mathrm{CO}_{2}$ pipelines for the $\mathrm{CCS}$ [10]. Subsidies, feed-in-tariffs and other economic instruments are used to overcome this price-gap but this requires considerable shifts in tax regimes and legislation.

However, even if new technologies are competitive with the existing ones, it takes time to build the human and industrial capacity to scale them up to substantial levels i.e. more than $10 \%$ of current production [11]. In 2007 world installed power generation capacity was around $4500 \mathrm{GW}$ and this is projected to increase to around $7800 \mathrm{GW}$ by 2030 [2]. Around $37.5 \mathrm{GW}$ newly installed wind capacity was added in 2009 [12]. With a capacity factor of around $0.25-0.4$ [13] this is equivalent to about 15 GW installed coal or nuclear capacity (assuming capacity factors of between 0.7 and 0.9) [14]. PV solar is still far from this level with a newly installed capacity of $5.4 \mathrm{GW}$ in 2008 [15]. With a capacity factor of around 0.14 [16] this is equivalent to $1.5 \mathrm{GW}$ installed coal or nuclear power. In order to contribute significantly to the global power generation capacity in 2030 the production of both wind and PV solar need to be scaled up dramatically.

Next to the economic issues and industrial capacity, discussions on spatial and infrastructure planning are common when new nuclear power plants, wind turbines and CCS projects are planned and this can slow down the implementation of these technologies considerably $[17,18]$.

\section{Analysis of $\mathrm{CO}_{2}$ emissions and metal requirements of different technologies}

Life Cycle Assessment (LCA) is used here to analyze the $\mathrm{CO}_{2}$ emissions and metal requirements of different technologies for power generation. In an LCA all emissions and extractions over the whole life cycle of products and services are considered. In this article we limit the scope to $\mathrm{CO}_{2}$ emissions and the metal requirements. Furthermore, we limit the study to the production of the electricity. This means that the transmission, distribution and use of the electricity are not included. This simplification might lead to a relative overestimation of material needs for distributed power generation options like rooftop PV and distributed wind power. Both of these options would reduce the amount of transmission capacity that is needed. However, in practice, large scale centralized wind and PV farms are needed in order to achieve a substantial contribution to the global electricity production $[6,19]$. Centralized wind and PV farms will actually increase the transmission network that is needed. Next to that, a substantial buffering infrastructure would be needed in order to facilitate a substantial share of the renewables in the electricity mix.

The production of the infrastructure, equipment and materials, the transport and mining of fossil fuels and raw materials that are needed for the electricity production are all taken into account. The

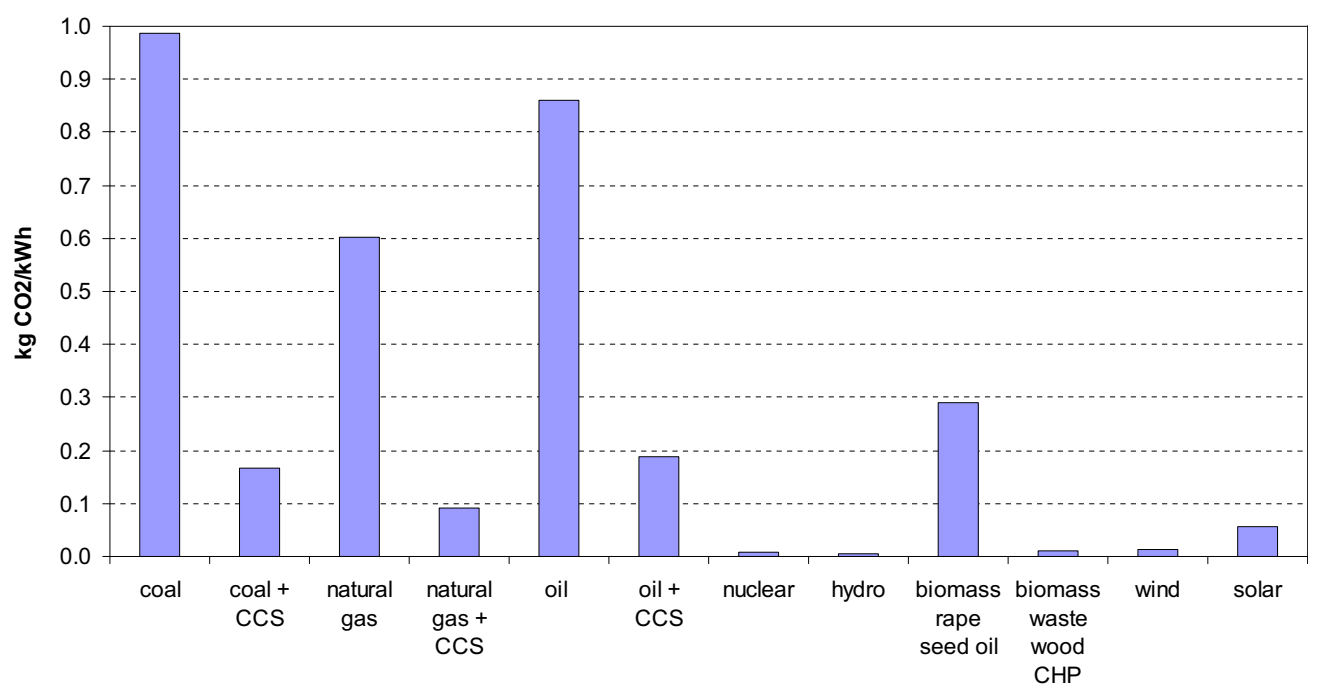

Fig. 1. $\mathrm{CO}_{2}$ emissions of different power generation technologies. 
functional unit of this LCA, which is the basis for comparison of the different technologies, is $1 \mathrm{kWh}$ of electricity delivered to the grid.

\section{Implications for mass deployment - three cases}

In order to assess the effectiveness with regard to $\mathrm{CO}_{2}$ emission reduction and the metal requirements, three cases for world electricity supply will be compared with a reference case (Table 1 ). The reference case is based on the 2007 energy mix for power generation as given by the IEA [3]. We defined two alternative cases based on different technologies to reduce global $\mathrm{CO}_{2}$ emissions: CCS and non-fossil energy sources. The cases are not meant to represent a realistic future electricity mix but they are used here as two extremes of the spectrum of low-carbon power generation. Future power generation will most likely consist of a mix of CCS and non-fossil electricity. Therefore, next to these extreme cases, a fourth case was introduced which was based on the electricity mix from IEA BLUE Map scenario as described in [10]. This mix was combined with the global electricity supply in 2007. For the electricity production part, the IEA BLUE Map case is based on a combination of low-carbon technologies and CCS.

The CCS case is identical to the reference case but all incineration based electricity (coal, natural gas, oil and biomass) is assumed to be connected to a CCS infrastructure. The non-fossil case assumes a power mix with an equal distribution over the different non-fossil technologies: 20\% nuclear, 20\% hydro, 20\% wind, 20\% PV and $20 \%$ biomass. Although this choice seems arbitrary, it is actually a reasonable reflection of the potential (and limitations) of each of these technologies. Intermittency of wind and solar will mean that buffering is needed and that it is sensible to mix them with other sources. Allocating $20 \%$ of the electricity mix to both seems therefore reasonable. Although recent growth in hydropower has been substantial and some large projects are still in the pipeline a limited increase from the current $15.6-20 \%$ of the mix seems reasonable to assume. The best locations for hydropower have been developed already and the environmental and social implications of large projects will limit it's growth potential. Nuclear power is back on the political agenda in developed countries and many developing countries are just beginning to explore its potential $[20,21]$. However, the lack of industrial capacity, risks of proliferation, limited capacity for the storage of nuclear waste and difficulties to scale up uranium supply are likely to limit the extent of the growth [22]. An expansion from the current $14 \%$ to $20 \%$ seems just doable. In the IEA BLUE Map case the contribution of fossil fuels is limited to $32 \%$ which is almost completely combined with CCS. Nuclear is scaled up to $24 \%$ and hydro scaled down (relatively) to $13 \%$. Solar and wind combined deliver $25 \%$, and $6 \%$ is derived from biomass. ${ }^{1}$

\section{Methods \& data sources}

LCA is used to calculate $\mathrm{CO}_{2}$ emissions and metal requirements per kWh electricity produced with different technologies. The LCA was performed using version 5.0 of CMLCA [23]. EcoInvent 2.0 (Frischknecht et al., 2007) was used as the LCA database for all electricity technologies and all background data and it was supplemented with additional data for Carbon Capture and Storage [24]. Abbreviations, descriptions and data sources of the different technologies are given in Table 2 . The basic data that was used for the natural gas and coal fired power plants with CCS is given in Table 3. For biomass two technologies have been analyzed which more or less represent a worst and best case. The 'best case' is

\footnotetext{
${ }^{1}$ It should be kept in mind that the IEA BLUE Map mix is based on the electricity production in 2030 which is assumed to be about double that of 2007 .
}

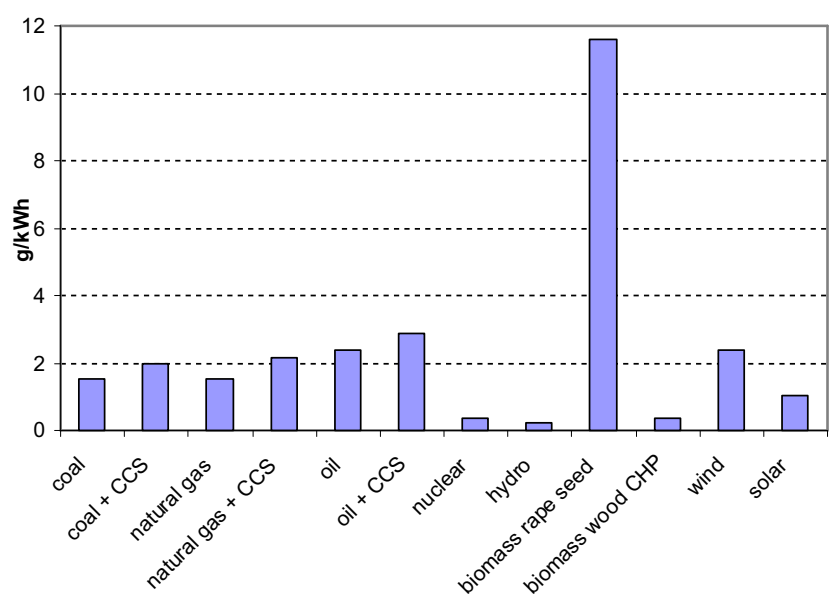

Fig. 2. Iron requirements in different power generation technologies.

Combined Heat and Power with waste wood chips as a source of biomass. The 'worst case' is rape seed oil which is fed into an oil fired power plant. The metal intensities and $\mathrm{CO}_{2}$ emissions of the different technologies are then multiplied by the total electricity demand and mix as given in Table 1 . This results in the total annual $\mathrm{CO}_{2}$ emissions and metal requirements for the current mix, the CCS mix and the non-fossil mix.

This bottom-up approach to calculate global $\mathrm{CO}_{2}$ emissions and metal requirements on the basis of individual technologies should be seen as rough estimations of actual emissions and metal requirements. In reality the mix of energy technologies is much more diverse than the one used here. Secondly, when the total energy production is used as the basis for calculations the substantial extra installed capacity which is needed for peakdemand is not taken into account. Finally, in the non-fossil scenario buffering will be needed because $40 \%$ of the sources (solar and wind) are intermittent by nature. This buffering can either be

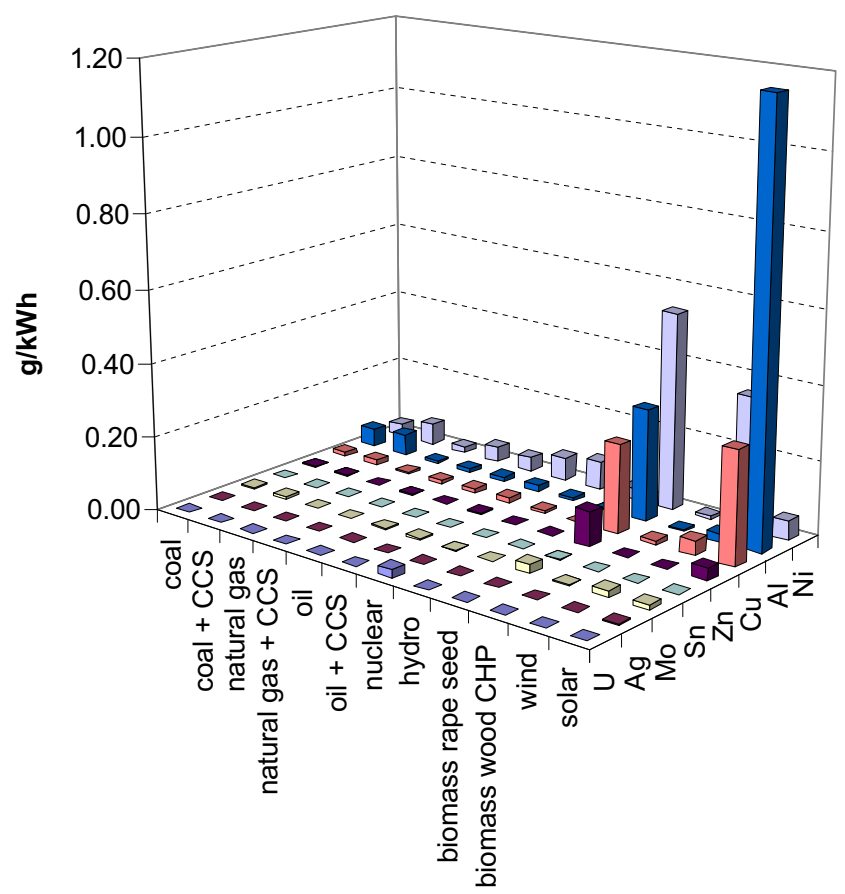

Fig. 3. Requirements of selected metals in different power generation technologies. 


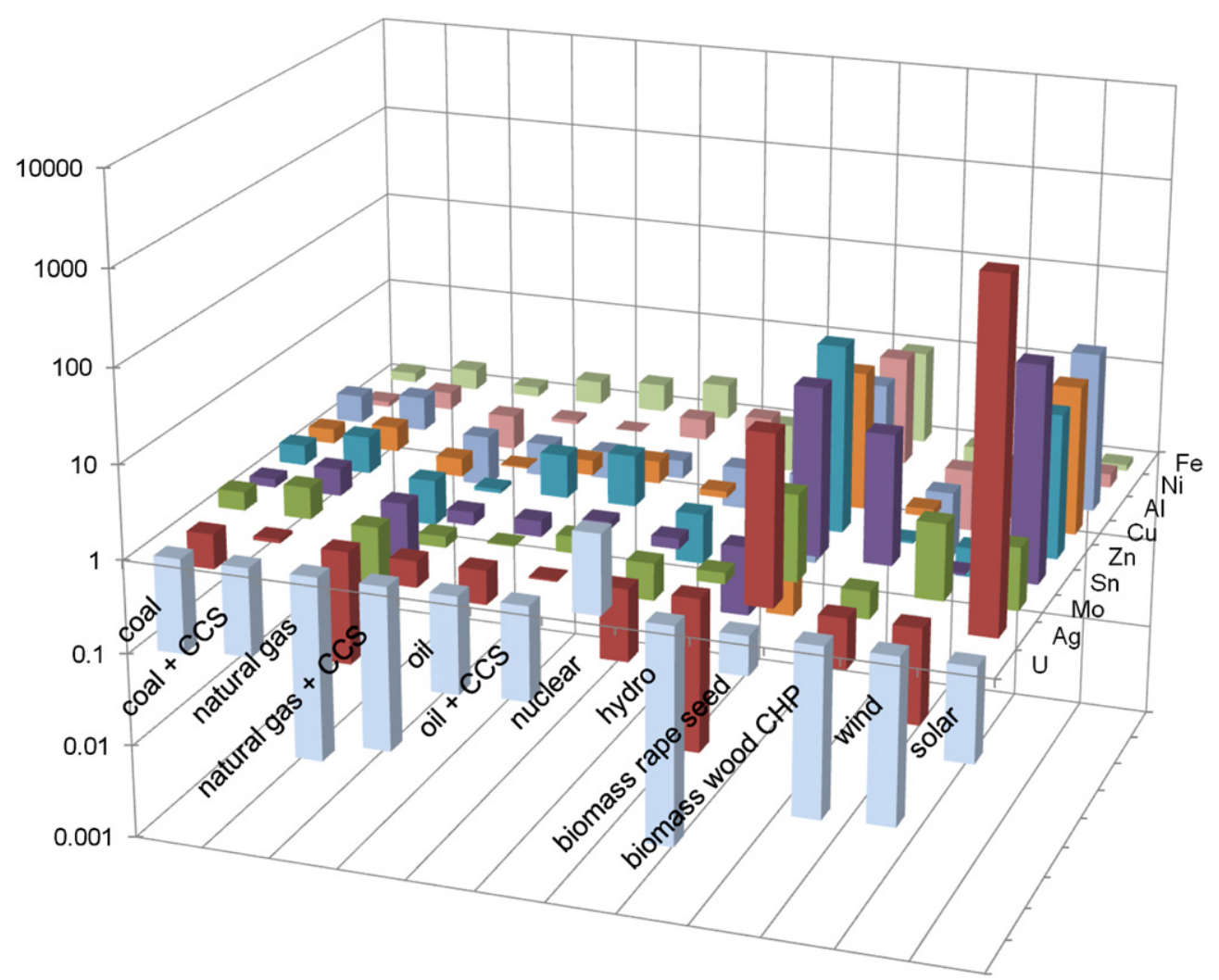

Fig. 4. Requirements of selected metals in different power generation technologies relative to the metal demand of the current mix.

done by installing back-up capacity of non-intermittent technologies like nuclear and biomass, or by adding storing options like compressed gas, pumped hydro, batteries etc. Both options will add to the metal requirements and increase $\mathrm{CO}_{2}$ emissions of the system as a whole. In this very simplified analysis we did not take these factors into account.
In a final step the reduction in $\mathrm{CO}_{2}$ emission is compared with the emission reduction of $50-85 \%$ below 2000 levels which is needed for stabilization of atmospheric $\mathrm{CO}_{2}$ concentrations. The metal requirements are compared with the annual global production of these metals. Data on annual global production are taken from the US Geological Survey [25].

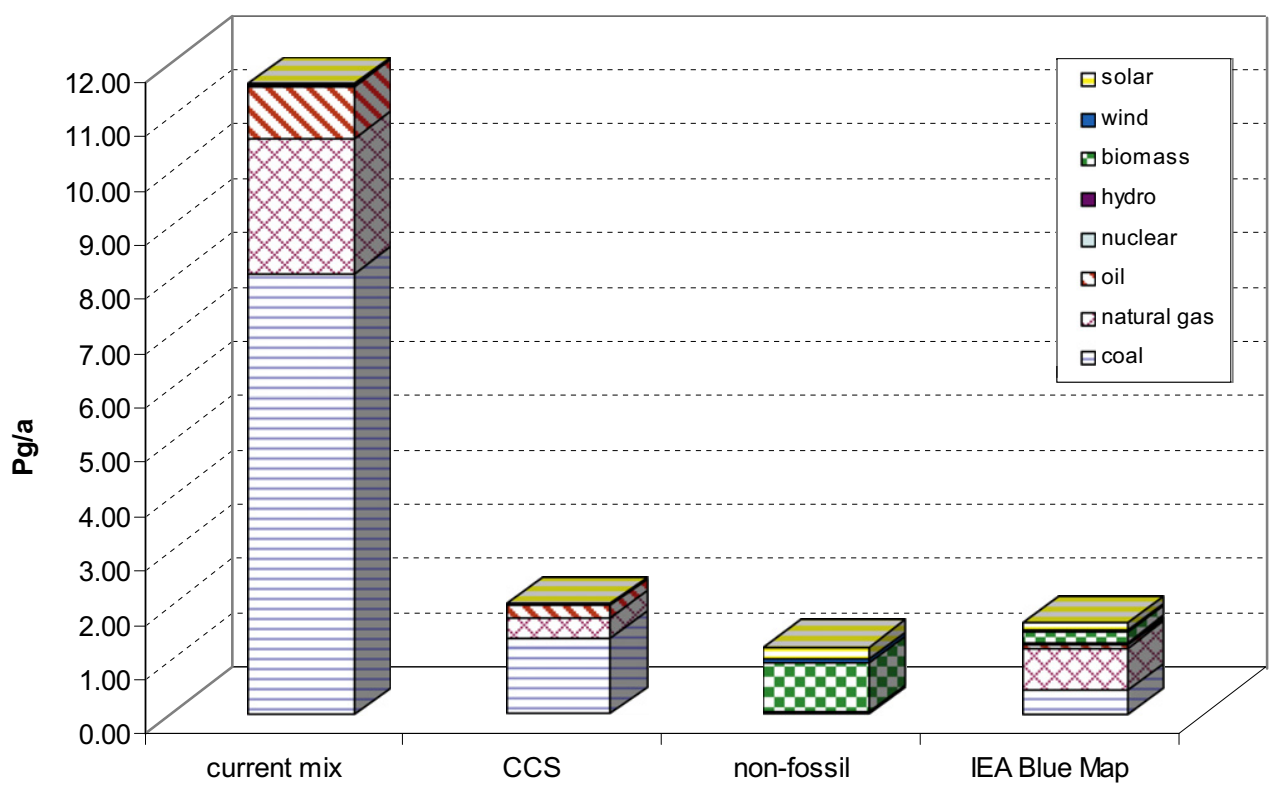

Fig. 5. $\mathrm{CO}_{2}$ emissions in the different power mix cases. 


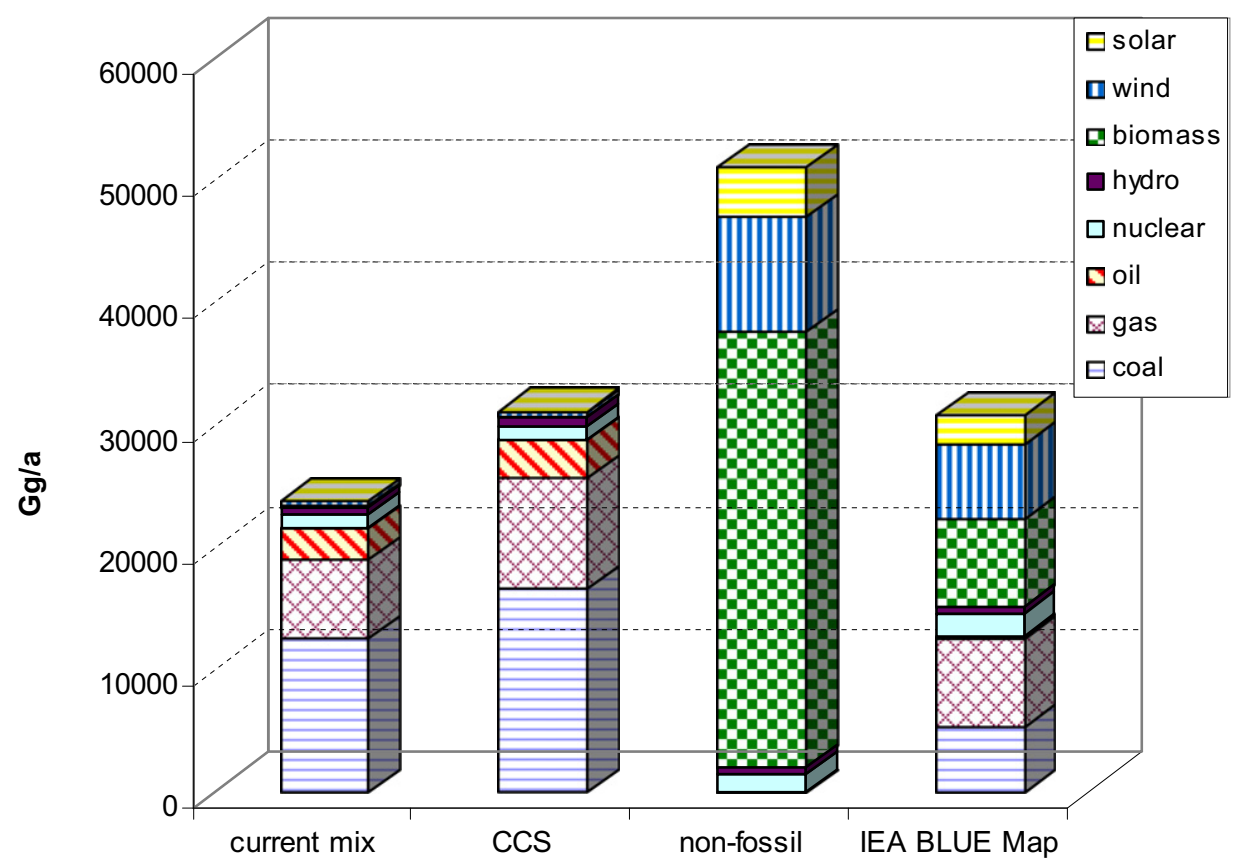

Fig. 6. Iron requirements in different power mix cases.

\section{Results}

\subsection{Analysis of the $\mathrm{CO}_{2}$ emissions and metal requirements of} individual technologies

The results of the calculations of $\mathrm{CO}_{2}$ emissions and metal requirements of the different electricity producing technologies are given in Figs. 1-3. Fig. 1 shows the $\mathrm{CO}_{2}$ emissions of different technologies. The application of $\mathrm{CCS}$, will reduce $\mathrm{CO}_{2}$ emissions from fossil fuel based power plants with a factor 10 . For biomass the emissions related to the use of rape seed oil are about half of those of natural gas fired power, without CCS. For the CHP with waste wood the emissions are a factor 30 lower. For nuclear, hydro and wind, $\mathrm{CO}_{2}$ emissions are very low but not zero. This is caused by the necessary production of equipment, capital goods and infrastructure. In a static attributional LCA, as we have used here, this uses the inputs of the current fossil fuel dominated energy system. For the same reason and because construction and production is relatively more material and energy intensive the emissions related to solar electricity are comparable with those of fossil fuels with CCS.

With regard to the metal requirements it is clear from Figs. 2 and 3 that CCS will increase the demand for iron and nickel substantially. For coal fired power plants, the increase is about $30 \%$ for iron and $75 \%$ for nickel. For gas fired power plants, it is about $40 \%$ for

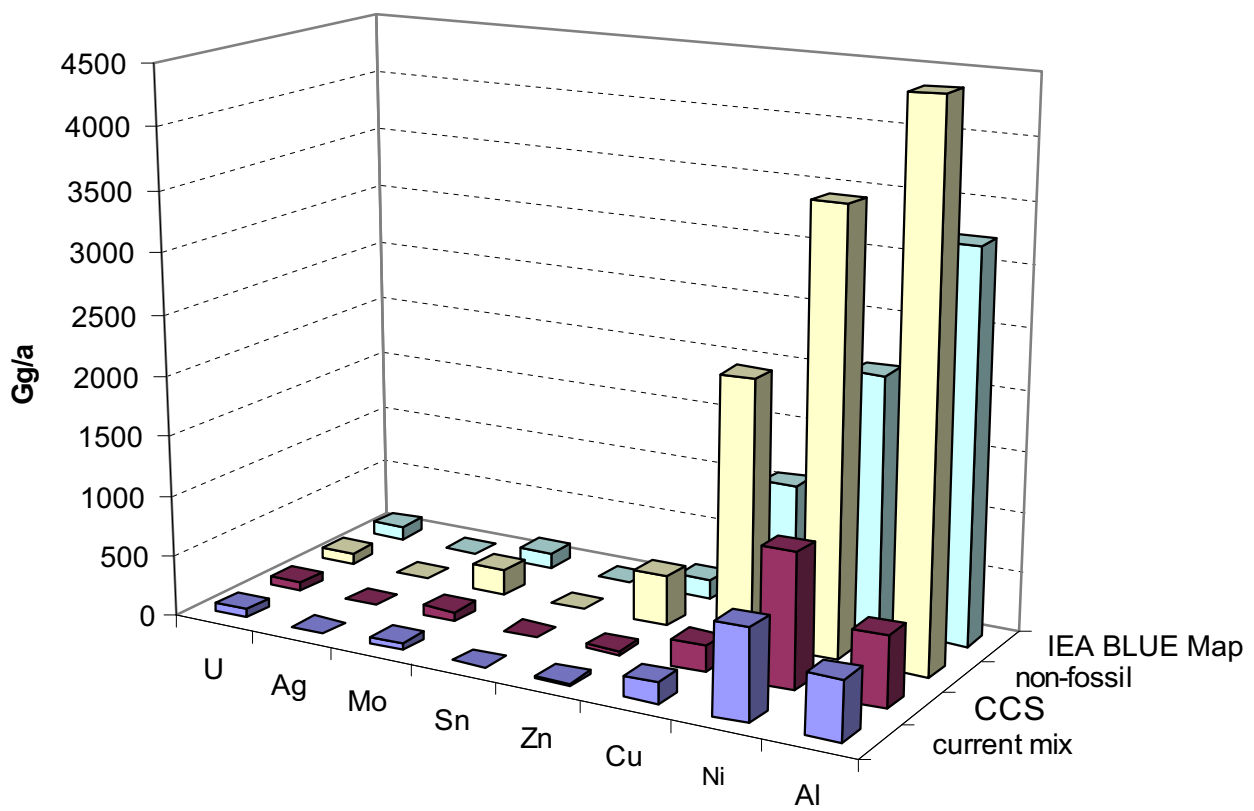

Fig. 7. Requirements of selected metals in different power mix cases. 


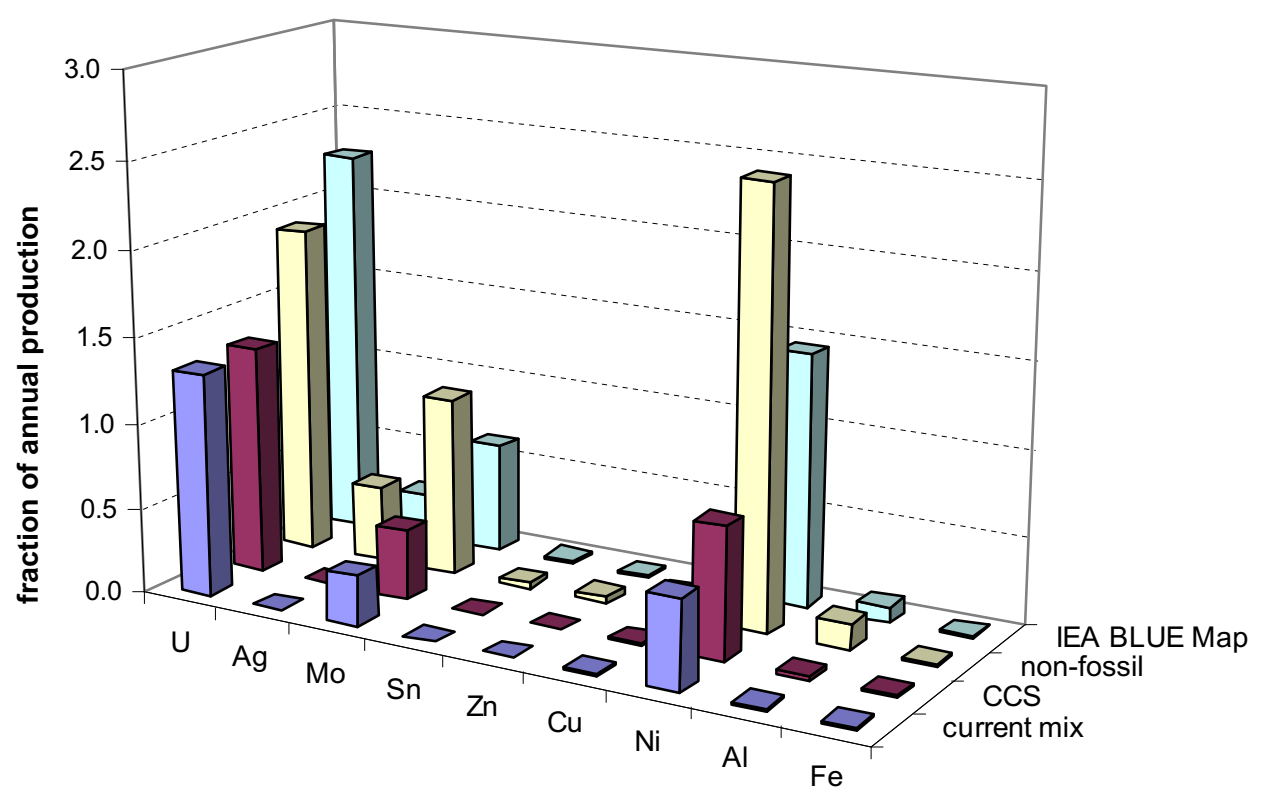

Fig. 8. Requirements of selected metals in different power mix cases compared with world annual mine production of these metals.

iron and $150 \%$ for nickel. This is caused by additional infrastructure, especially the pipelines and the additional capacity needed to compensate for the loss in efficiency. Wind requires 20\% more iron than coal plus CCS and solar is in the same range as natural gas power plants. Biomass energy based on rape seed oil requires about five times as much iron per kWh electricity produced than regular fossil fuel based energy. The reason for this lies in agricultural production of the biomass, which requires substantial inputs like fertilizers and capital goods per unit biomass produced. The intensity for other metals is given in Fig. 3 and is especially high for the all new non-fossil technologies like rape seed based biomass, PV solar and wind. For biomass the reason is again the high amounts of fertilizers and capital goods required. For wind and solar it is metal intensive turbines and solar panels and their production.

In Fig. 4 the material demand of different technologies is given relative to the metal demand of the current electricity mix. It is clear that requirements for most metals are higher in the case of CCS, but much more so in the case of non-fossil technologies.

\subsection{Analysis of the $\mathrm{CO}_{2}$ emissions and metal requirements at world scale implementation - the three cases}

In Fig. 5 the $\mathrm{CO}_{2}$ emissions of the three different cases and the reference case are given. The $11.6 \mathrm{Pg}$ of annual $\mathrm{CO}_{2}$ emissions from power generation compares well with the $11.9 \mathrm{Pg} / \mathrm{a}$ which is given by the IEA [4]. However, in contrast to the IEA figures, the emissions we calculated are "life cycle" emissions which means that the emissions of the production of the fuels and capital goods and all other upstream processes are included in the $11.6 \mathrm{Pg} / \mathrm{a}$. Since over $90 \%$ of the life cycle $\mathrm{CO}_{2}$ emissions from gas and coal based electricity originate from the power plants themselves and less than $10 \%$ from the background processes this still means the bottom-up figures we calculated are in correct order of magnitude. At an assumed $90 \%$ capture rate at the power station, CCS reduces the life cycle emissions to around $17 \%$ of the emissions in the current mix. The non-fossil case reduces the emissions just a little extra to about $10 \%$ of the current mix. The IEA BLUE Maps scenario is about as effective as the other two cases. All three cases are thus more or less equally efficient in reducing $\mathrm{CO}_{2}$ emissions. All three fall well within the range of emission reductions (50-85\%) that are necessary to stabilize atmospheric $\mathrm{CO}_{2}$ concentration to levels around $450 \mathrm{ppm}$.

Figs. 6 and 7 show the metal requirements for the CCS, nonfossil, IEA BLUE Maps cases in relation to the current mix. The CCS case requires an annual input which is $10 \%$ (silver) to $40 \%$ (nickel) higher than that in the current mix. For uranium the annual requirement remains constant as the nuclear fraction in the mix remains constant in this case. The non-fossil case requires far more metals than the current mix: between 1.5 times (uranium) and almost 800 times (silver) the amount in the current mix.

Whether these increases are important becomes more clear, when the requirements for power generation are compared with current annual mine production. Fig. 8 shows the annual metal requirements in the three cases and reference case, given as a fraction of the 2009 world mine production of these metals. From this analysis it is clear that the increases of metal requirement of iron, tin, and zinc are relatively insignificant when compared to current mine production. However, the increases in requirements in the non-fossil case for aluminum (1-15\%), nickel (50-250\%), molybdenum (30-100\%) and silver (0-44\%) but also uranium (130-190\%) would have a significant impact on the mining of these metals. In the CCS case the material requirements are less but still significant. Nickel demand would go from about $60 \%$ to over $80 \%$ of the annual production and for molybdenum from about $30 \%$ to $40 \%$. In the IEA BLUE Maps case the material requirements are in between as expected.

\section{Conclusions and discussion}

About $40 \%$ of global $\mathrm{CO}_{2}$ emissions originates from the production of power. In this paper, we have analyzed to what extent these emissions can be reduced, by the use of low-carbon technologies (CCS, nuclear and renewables) and what the consequences would be with regard to the metal requirements. All three electricity mixes presented here (CCS, non-fossil and IEA BLUE Maps) result in a reduction of about $80-90 \%$ of $\mathrm{CO}_{2}$ emissions, if comparable reductions would be achieved in other sectors the 450-490 ppm stabilization goals could be realizable. However, in all three cases presented here this comes at a cost of higher metal requirement. 
The addition of CCS to the current electricity mix, would influence the annual demand for nickel and molybdenum substantially. Applying CCS requires $10-30 \%$ percent more metals than the current electricity mix (Fig. 8). This is a result of the additional infrastructure that is needed to capture, transport and store $\mathrm{CO}_{2}$ (specialty steels), in combination with a reduced efficiency of the power plants.

The switch to a non-fossil electricity mix would result in a much higher demand for nickel, uranium, silver, molybdenum and, to a lesser extend, copper and aluminum. For PV solar, non-waste biomass and wind the increase in metal use ranges from a few percent to a factor thousand. This means that mining of these metals would have to be scaled up considerably in order to fulfill the demand for these new electricity technologies (Fig. 8). Not all non-fossil technologies are more metal intensive than fossil fuel based power. Nuclear power, hydropower and waste biomass have a relatively low metal intensity. PV solar, non-waste biomass and wind, however, are much more metal intensive than the current mix. For PV solar and wind the increase is related to the relatively high metal intensity of PV solar cells and wind turbines. For nonwaste biomass it is related to the need for relatively material intensive agricultural processes including the production of agricultural machines and the production of fertilizers.

The last couple of decades a trend of decreasing material intensity per unit of GDP produced has been found in many developed countries [26,27]. However, when climate change forces these economies to switch to alternative energy sources, for the energy sector, this trend is broken.

The type of material demand in different technologies depends strongly on the specific technologies that are chosen. For example, the extremely high demand for silver in solar electricity is related to the choice for mono-crystalline silicon PV cells. However, other PV solar technologies have material demand issues of their own [7]. Current thin film CdTe and CIGS will run into scarcity issues long before they will contribute significantly to the global power generation [6]. The $2 \mathrm{MW}$ offshore wind turbine with a geared generator that we used in this study does not require neodymium based permanent magnets. However, the new, more efficient and low-maintenance direct-drive turbines use about $150 \mathrm{~kg}$ Nd per MW $[6,28]$. Scaling up these technologies to the level of tens of GW would require a dramatic increase in the production of this rare earth metal.

Next to PV solar, wind and biomass electricity other renewable technologies like ocean renewables and PV thermal are available as well. Some first results show that ocean renewables have an even higher metal intensity than the technologies discussed here. The amount of iron needed in the equipment itself (excluding the life cycle) for wave and tidal energy is between 8 and $10 \mathrm{~g} / \mathrm{kWh}$ [29], which is four to five times as high as the life-cycle iron intensity for wind turbines.

We did not analyze any changes in the grid related to the different technologies. However, it is clear that the CCS options would require little or no changes to existing transmission and distribution infrastructure, while the large scale introduction of PV and wind would require substantial changes in the electricity infrastructure. Roof PV relocates electricity production to the electricity consumers and it will thereby reduce the transmission load in the network. In contrast, centralized PV and wind power, especially of-shore, will relocate and probably increase the infrastructure needed for transmission. This will increase the metal requirements of these technologies considerably, especially for copper and aluminum.

The analysis presented here is a static analysis in which the dynamics of the transition to a low-carbon electricity system are not discussed. However, if climate goals are to be met a fast transition to a low-carbon power sector is needed. If the power sector will be transformed in the next two or three decades, based on current technologies, it is clear that this will cause a significant peak in metal demand. Uncertainties about the long term climate policy and technology choices will make it difficult for mining companies to anticipate such a peak. Further research is needed to explore the dynamics of the metal demand connected to the energy transition.

In this work we only looked at the electricity sector. However, the energy transition will also lead to increased material demand in other sectors. One of the most important ones will be the automotive sector. Hybrids and plug-in hybrids, full electric vehicles and fuel cell vehicles will all require metals in high tech parts like batteries, electro motors (including permanent magnets) and fuel cells [6]. At the same time the introduction of these vehicles will considerably increase the demand for electricity.

Whether or not material requirements induce material scarcity will depend on a host of things, but specifically also on the possibilities for substitution $[30,31]$. In many of the technologies described here, material substitution may potentially reduce the requirement of specific metals. Silver in PV solar cells might be replaced by other metals. PV solar cells can be made on a completely new basis e.g. FeS cells. Nickel and molybdenum containing steels might be replaced by steels containing other alloys or by new strong and inert composite materials. Concrete might be used to substitute for the steel towers of wind turbines. Aluminum can substitute copper as a conductor. Extensive agriculture which produces high cellulosic biomass might substitute for the highly intensive oil producing agriculture. However, there is a limit to which this substitution is possible. It is not likely that completely new carbon based materials will replace basic materials like steel and other metals in the near future [31]. There is a limited number of elements available and at the moment almost all of them have useful applications. Shifting from one to the other will therefore in many cases simply shift the problems of material availability from one sector to another. In addition, substitution that is forced by looming scarcity - in contrast to substitution induced by product improvement - could very well slow down the energy transition and reduce overall efficiency, as material choices are forced by scarcity and the technically "optimal" solutions cannot reach their full potential.

Energy and mining are linked to each other in two directions: not only are materials needed for building (new) energy infrastructures but, the other way around, huge amounts of energy are needed during mining, reduction and refining of metals. Increased mining will lead to additional energy use. Dwindling ore grades and the use of less accessible resources will increase energy demand per $\mathrm{kg}$ of metal [32]. This will result in considerably higher $\mathrm{CO}_{2}$ emission levels providing a less optimistic picture of GHG benefits of low-carbon energy pathways.

Until now technological developments in mining and processing of metals have more than compensated for the dwindling ore grades and increasing demand, keeping metal prices relatively low [33-36]. The peaks we have seen in metal prices in the past can almost always be explained by peaks in demand that outpaced the capability miners and processors to increase supply. However, there are indications that the latest mismatch between demand and supply, the 2002-2008 metal boom, was at least partly caused by more fundamental problems at the supply side [37,38].

The transition to a sustainable energy system is a prerequisite for a sustainable future but there are hurdles, some of which are not that obvious. In the end, changing the worlds energy system to reduce GHG-emissions is a huge operation with huge implications for the worlds material system as well. There are all kinds of feedback mechanisms and dynamics involved that make it difficult to oversee all implications. This paper shows, at least, that using diffuse energy sources instead of concentrated sources 
substantially increases metal requirements for harvesting the energy. It also shows that adding emission reduction technologies to the existing fossil fuel based energy systems increases metal requirements, be it to a lesser extent. Whatever the future energy system will look like, at least we can be sure that the days of "easy", i.e. material-extensive energy, are over. It is very important to explore all the implications of such a change to support the transition to a new energy system, in order to make it a sustainable system and catch any drawbacks in an early stage.

\section{Role of funding source}

This study has partly been funded by a research grant from Shell. Shell has provided some of the information on CCS technologies. This data has been combined with data on CCS from literature. One of the co-authors, Gert Jan Kramer, is a Shell employee, next to his affiliation as a full professor at the faculty of Science at Leiden University.

\section{References}

[1] Fouquet R. Heat, power and light. Cheltenham: Edward Elgar; 2008.

[2] International Energy Agency. World energy outlook 2009. Paris: IEA; 2009.

[3] International Energy Agency. IEA statistics online. International Energy Agency; 2009.

[4] International Energy Agency. $\mathrm{CO} 2$ emission from fuel combustion. Paris: IEA; 2009. 2009 edition, Highlights.

[5] Metz B, Davidson OR, Bosch PR, Dave R, Meyer LA. Technical summary. In: I.P.C.C, editor. Climate change 2007: mitigation. contribution of working group iii to the fourth assessment report of the intergovernmental panel on climate change. New York: Cambridge University Press; 2007.

[6] Kleijn R, van der Voet E. Resource constraints in a hydrogen economy based on renewable energy sources. Renewable and Sustainable Energy Reviews 2010;14(xxx).

[7] International Energy Agency. Energy technology perspectives. Paris: EIA; 2008.

[8] Raugei M, Frankl P. Life cycle impacts and costs of photovoltaic systems: current state of the art and future outlooks. Energy 2009;34(3):392-9.

[9] Kammen DM, Pacca S. Assessing the costs of electricity. Annual Review of Environment and Resources 2004;29(1):301-44.

[10] Hammond GP, Akwe SSO, Williams S. Techno-economic appraisal of fossilfuelled power generation systems with carbon dioxide capture and storage. Energy 2011;36(2):975-84.

[11] Kramer GJ, Haigh M. No quick switch to low-carbon energy. Nature 2009; 462(7273):568-9.

[12] Global Wind Eenergy Council. Global wind power boom continues despite economic woes. Brussels: GWEC; 2009.

[13] Global Wind Energy Council. Large scale integration of wind energy into electricity grids. Global Wind Eenergy Council; 2010.

[14] U.S. Energy Information Administration. Electric power industry 2008: year in review. U.S. Energy Information Administration; 2010.

[15] REN21. Renewables Global Status Report 2009 update. Paris: Renweable Energy Policy Network for the 21st century; 2009. http://www.ren21.net/.

[16] Schiermeier Q, Tollefson J, Scully T, Witze A, Morton O. Energy alternatives: electricity without carbon. Nature 2008;454(7206):816-23.
[17] Kintisch E. Out of site. Science 2010;329(5993):788-9.

[18] Kintisch E. Other siting problems. Science 2010;329(5993):789.

[19] MacKay DJC. Sustainable energy - without the hot air. Cambridge: UIT Cambridge Ltd; 2009.

[20] International Atomic Energy Agency. Nuclear technology review. Vienna: IAEA; 2009. p. 133.

[21] Guang Y, Wenjie H. The status quo of China's nuclear power and the uranium gap solution. Energy Policy 2010;38(2):966-75.

[22] Lior N. Energy resources and use: the present situation and possible paths to the future. Energy 2008;33(6):842-57.

[23] Heijungs R. CMLCA: scientific software for LCA CML. Universitiet Leiden; 2010.

[24] van der Giesen C. Metals matter, assessing life cycle material demands of carbon capture and storage [MSc]. Leiden: Leiden University; 2008.

[25] U.S. Geological Survey. Mineral commodity summaries 2010. U.S. Geological Survey; 2010. p. 193.

[26] Moll S, Bringezu S, Schütz H. Resource use in European countries. Wuppertal: Wuppertal Institute; 2005. p. 105.

[27] van der Voet E, van Oers L, Moll S, Schütz H, Bringezu S, de Bruyn S, et al. Policy review on decoupling: development of indicators to assess decoupling of economic development and environmental pressure in the EU-25 and AC-3 countries. Leiden University Wuppertal Institute for Climate, Environment and Energy CE Solutions for Environment, Economy and Technology. Leiden Institute of Environmental Sciences (CML); 2005. p. 159.

[28] Polinder H, van der Pijl FA, de Vilder G-J, Tavner PJ. Comparison of direct-drive and geared generator concepts for wind turbines. IEEE Transactions on Energy Conversion 2006;21(3):8.

[29] Kluts I. Material use of ocean renewable energy technologies. Leiden University; 2009.

[30] Goeller HE, Weinberg AM. The age of substitutability. Science 1976; 191(4228):683-9.

[31] Ayres RU. On the practical limits to substitution. Ecological Economics 2007; 61(1):115-28.

[32] Norgate TE. Deteriorating ore resources. In: Graedel TE, Evd Voet, editors. Linkages of sustainability. Cambridge, MA: MIT Press; 2010. p. 532.

[33] Radetzki M, Eggert RG, Lagos G, Lima M, Tilton JE. The boom in minera markets: how long might it last? Resources Policy 2008;33(3):125-8.

[34] Radetzki MA. Handbook of primary commodities in the global economy. Cambridge UK: Cambridge University Press; 2008.

[35] Gordon RL. Hicks, hayek, hotelling, hubbert, and hysteria or energy, exhaustion, environmentalism, and etatism in the 21st century. Energy Journal 2009; 30(2):1-16.

[36] Solow RM. The economics of resources or the resources of economics American Economic Review 1974;64(2):1.

[37] Mudd GM. The environmental sustainability of mining in Australia: key megatrends and looming constraints. Resources Policy 2010;35(2):98-115.

[38] Humphreys D. The great metals boom: a retrospective. Resources Policy 2010; 35(1):1-13.

[39] Frischknecht R. AH-J, Doka, G., Dones, R., Heck T., Hellweg, S., Hischier, R.et al. Overview and Methodology. Final report ecoinvent v2.0 No. 1. Duebendorf CH.: Swiss Centre for Life Cycle Inventories; 2007. http://www.ecoinvent.ch/.

[40] Ramezan M, Skone TJ. Revised November 2007 ed. In: Carbon dioxide capture from existing coal-fired power plants. : National Energy Technology Laboratory; 2007.

[41] Fluor, Statoil. Study and estimate for $\mathrm{CO} 2$ capture facilities for the proposed $800 \mathrm{mw}$ combined cycle power plant. Norway: Tjeldbergodden; 2005. p. 55.

[42] Odeh NA, Cockerill TT. Life cycle GHG assessment of fossil fuel power plants with carbon capture and storage. Energy Policy 2008;36(1):367-80.

[43] Spath PL, Mann MK. Biomass power and conventional fossil systems with and without $\mathrm{CO}_{2}$ sequestration - comparing the energy balance, greenhouse gas emissions and economics. National Renewable Energy Laboratory; 2004. 